\title{
Panji in the Age of Motion

\author{
An investigation of the development of \\ Panji-related arts around Java
}

\author{
ADRIAN PERKASA
}

\begin{abstract}
The first half of the twentieth century in Indonesia is often remembered as the Age of Motion. The term "motion" (pergerakan) is invariably used in history textbooks for students and in the official Indonesian historiography: Sejarah nasional Indonesia (Kartodirdjo, Poesponegoro, and Notosusanto 1975; Poesponegoro and Notosusanto 2008) and in the new edition, Indonesia dalam arus sejarah (Lapian and Abdullah 2012). Political movements in Indonesia always dominated the discourses of pergerakan at the expense of developments in other sectors, including culture. This cultural development, particularly in Java, was intricately intertwined with the upsurge in Javanese and then Indonesian nationalism, an expansion of modernity and Islamic revivalism. Topeng Panji with all of its forms around Java is symptomatic of this development. This paper is an initial investigation into the developments of topeng Panji across Java in the Age of Motion. By tracing the social and cultural histories from the perspective of the bureaucrats, artists, and government officials who wrote in books, journals, and other contemporary sources, this study aims to highlight topeng Panji and its development during that period.
\end{abstract}

KEYWORDS

Panji; topeng; Java; Indonesia; nationalism; cultural history.

\section{WESTERN EDUCATION AND THE NATIONALIST IDEA IN INDONESIA}

The early twentieth century is known as the Age of Motion (masa pergerakan) in Indonesian historiography. This era was marked by the emergence of many modern organizations, including Boedi Oetomo in 1908, Sarekat Islam in 1911,

\footnotetext{
ADRIAN PERKASA is a lecturer in the Department of History, Faculty of Humanities, Universitas Airlangga, Surabaya. Currently, he is a PhD candidate at the Leiden University Institute of Area Studies (LIAS), Faculty of Humanities, Universiteit Leiden, the Netherlands on a scholarship from the Indonesia Endowment Fund for Education or LPDP Indonesia. Adrian Perkasa can be reached at: adrianperkasa@fib.unair.ac.id or a.perkasa@hum.leidenuniv.nl.
}

(C) 2020 Faculty of Humanities, Universitas Indonesia

ADRIAN PERKASA | DOI: 10.17510/wacana.v21i2.887. 
and the Indische Partij in 1912. ${ }^{1}$ These developments were the outcome of a sea change in colonial government policies, especially in education. The founders, functionaries, and prominent members of these groups had been educated in modern government schools which used Dutch as the primary language of instruction. These groups emerged as a new cluster in the elite in the Netherlands East Indies, particularly in Java. In the previous era, particularly before the 1850s, noble families or priyayi dominated the elite group. They sent their children to Islamic boarding schools or pesantren to imbibe Islamic and Javanese knowledge before they succeeded their fathers in the administrative office. However, changes began to creep in the second half of the nineteenth century. The rapid industrialization and bureaucratization or the state required a ready supply of trained employees, with the expertise which could only be supplied by western education. When he was serving as Minister of Colonies in 1845, J.C. Baud put forward a policy which would give the indigenous people a proper education. However, his hope was not realized until 1851 with the passing of a government decree on indigenous education. Initially the plan for the educational organization was simple. It consisted of a teachers' college and a block of provincial or residency schools, one in each residency, and it would be limited to Java and not introduced the other islands in the Archipelago (Kroeskamp 1974: 300-301).

The schools were established for young people who, by birth, were destined to fill an administrative function. For generations these functions had been held by the high-ranking families of bupati (regents), patih (governors), and wedana (district chiefs) in Java. However, with the new legislation school attendance was not limited to the upper echelons and many children and young men from lower social status families also attended the schools. The Annual Reports on Education in the Netherlands-Indies (Algemeen Verslag van den Staat van het Schoolwezen in Nederlandsch-Indië) from 1853 and 1859 record many of the challenges and problems. Despite the lack of facilities and infrastructure, the most significant obstacle to getting indigenous children into modern schools was thought to be the parental preference for traditional Islamic schools, known as pesantren. Because of their religious convictions and affiliations parents forbade their children to attend the modern schools. They did not want to send their children to go attend an "infidel" institution (Moriyama 2013: 75). This attitude persisted until after 1870 when the colonial government introduced changes which altered the parents' attitude to western schools. The liberal trend which had emerged in the home country ordered the colonial government to exclude all religious instruction from schools. The government took this neutrality so far it withheld its subsidy from any private schools which did give religious education in any form in school hours.

The range of schools offering western education covered a gamut from the Kweekschool (teachers' training colleges), Hoofdenschool (chiefs' schools), then renamed Opleidingscholen voor Inlandsche Ambtenaren/OSVIA

${ }^{1}$ Regarding this concept of motion and the particular movement in Central Java during this period, see Takashi Shiraishi (1990). 
(Training Schools for Native Bureaucrats), the Dokter Djawa school renamed School tot Opleiding van Inlandsche Artsen/ STOVIA (Indigenous Medical Doctors' Schools). Consequently, after 1870, education not only served the people more effectively by supplying better-trained Javanese/Indonesian teachers, civil servants, and medical doctors but also had an indispensable share in bringing about social change in indigenous society. It raised the demand for a more meticulous control of the administration and even encouraged the emergence of national awareness. As Miroslav Hroch (2000: 22-23) has suggested in his comparative analysis of the social composition in number of nations of Europe, there were three phases of the national movements: the period of scholarly interest or Phase A, the period of patriotic agitation or Phase B, and the rise of a mass national movement or Phase C. In its first phase, every national revival is marked by a passionate concern on the part of group of individuals, usually intellectuals, for the study of the language, culture, and history of the oppressed nationality. These individuals did not exercise any widespread social influence and they usually did not even attempt to initiate any patriotic propaganda. Their interest was motivated by a lively affection for the region in which they lived, associated with a thirst for knowledge about every new and insufficiently investigated phenomenon. I call these phenomena cultural developments and they are often ignored in Indonesian historiography, especially in the Age of Motion period.

These trajectories are also discernible in the Indonesia nationalist movement. In the first phase, various intellectuals were motivated by a passion for the study of the culture of the indigenous people. In the nineteenth century, the Bataviaasch Genootschap van Kunsten en Wetenschappen (Royal Batavia Society for Arts and Science) already had a number of indigenous members. The emergence of an intellectual network like the Java-Instituut in 1919 can also be counted part of this development. The second phase began in the 1910s and 1920s, when patriotic sounds began to emerge, initially echoed by the Indo-Javanese group followed by other ethnic groups in the Netherlands East Indies. Many youth organizations founded on ethnicity were founded in this period. This social and intellectual current culminated at the end of 1920s in the foundation of a mass national party, Perserikatan Nasional Indonesia (then Partai Nasional Indonesia), led by Soekarno. The earliest scholars of the Indonesian nationalist movement like Kahin (1952), Anderson (1983), Legge (1988), and Shiraishi (1990) only paid attention to the Phases B and C, highlighting the patriotic agitations and the appearance on the scene of mass national movements and their struggle to achieve national independence.

However, theirs is a rather simplistic narrative. This particular situation had already also been observed by a contemporary activist, Tamzil. In the Jubileum-nummer of Perhimpunan Indonesia, Tamzil (1938) wrote:

[...] there is a clear dividing-line between so-called "cultural-nationalists" and "political-nationalists"; a difference, not about the uplifting of the Indonesian people, but more concerned with the role that "culture" and "politics" will have to play in the development of the people. On the one hand, the "cultural- 
nationalists" believe that the main task before us is the struggle for culture in the broadest sense of the word, accompanied by the struggle for social and economic enlightenment [...] The political nationalists, on the other hand, say that the main task is and remains the pursuit of the expansion of the political rights of the Indonesian people. Of course, you also have to fight for social and economic progress; the fight for more education and the like is also indispensable but, in general, from their point of view, cultural demands are subordinate to the pursuit of political rights, since cultural development can only fully flourish if the Indonesian political movement has greater political influence and power! [...] In the meantime, as already mentioned, these two extreme views, in particular, political nationalists, are losing supporters. Growing numbers of people in this group are convinced, not least by the hard blows of the crisis years, that the struggle for culture is an important factor in the national struggle. The best proof of these changing views is the Indonesian Language Congress at which politicians and non-politicians worked together and came to the conclusion that the development of the Bahasa Indonesia is essential to the further progress of the Indonesian people, both culturally and politically. This congress has been a success and a promising start for co-operation between all Indonesian nationalists. However, the saying "nothing is perfect" is true for the umpteenth time, because the Indonesian side has tried to diminish and obscure the value of this cultural movement. We would have disregarded this "disguise" if it had not made its way into so many Indonesian journals and if the articles in question had not been written by Hadji Agoes Salim, someone who plays a leading role in the national movement [...]. ${ }^{2}$ [My English translation.]

${ }^{2}$ [...] Tussen de z.g. "cultuur-nationalisten" en de "politiek-nationalisten" loopt een duidelijke, hoewel met de dag vager wordende scheidingslijn; een verschil, niet wat betreft de verheffing van het Indonesische volk, maar meer omtrent de rol die enerzijds de "cultuur" en anderzijds de "politie" heeft te spelen in de ontwikkeling van het volk. De "cultuur-nationalisten" zijn de mening toegedaan, dat de voornaamste taak die voor ons ligt, de strijd is voor de cultuur in de uitgebreidste zin des woords, gepaard gaande met de strijd voor economische en sociale verheffing [...] De "politiek-nationalisten" daarentegen zeggen, dat de voornaamste taak is en blijft: het streven naar uitbreiding van de politieke rechten van het Indonesische volk. Natuurlijk moet hiernaast ook gestreden worden voor sociale en economische verheffing; ook blijft onmisbaar de strijd voor meer onderwijs, enz., maar in het algemeen zijn volgens hun opvattingen de culturele eisen ondergeschikt aan het streven naar politieke rechten, omdat de culturele ontwikkeling zich pas volledig kan ontplooien als de Indonesische politieke beweging over grotere politieke invloed en macht beschikt! [...] ondertussen, zoals reeds gezegd, verliezen deze beide extreme opvattingen aanhangers, in het bijzonder de politiek-nationalisten. Hoe langer hoe meer komt men in deze groep tot de overtuiging, niet het minst door de harde slagen der crisis-jaren aan de politieke beweging toegebracht, dat de strijd voor de cultuur een belangrijke factor is in de nationale strijd. Het beste bewijs voor deze veranderende opvattingen is het Congres voor de Indonesische taal, waar politici en niet-politici samen hebben gewerkt en samen tot de opvatting zijn gekomen, dat de ontwikkeling van de Bahasa Indonesia noodzakelijk is voor de verdere vooruitgang van het Indonesische volk, zowel in cultureel als in politiek opzicht. Dit congres is een succes geweest en een veelbelovend begin voor de samenwerking van alle Indonesische nationalisten. Maar het gezegde "niets is volmaakt", wordt voor de zoveelste keer bewaarheid, want van Indonesische zijde heeft men alsnog getracht de waarde betekenis van deze culturele beweging te verkleinen en te verdoezelen. Wij zouden deze "verdoezeling" veronachtzaamd hebben, indien deze niet in vele Indonesische bladen was doorgedrongen en indien de betreffende artikelen niet geschreven waren door Hadji Agoes Salim, dus iemand die een leidende rol speelt in de nationale beweging [...]. (Tamzil 1938: 238-240). 
This piece aptly demonstrates that the political-nationalist groups had previously thought that their position was the right direction in which Indonesia should go and, of course, this diverged from the vision of the cultural nationalists. In short, political movements in Indonesia invariably dominated the discourses of Pergerakan or Motion and neglected the development in other sectors, including that of culture. Their dominance is an inescapable fact in the standard history textbooks for students and the official Indonesian historiography, Sejarah nasional Indonesia, Volume VI (Kartodirdjo, Poesponegoro, and Notosusanto 1975; Poesponegoro and Notosusanto 2008) and the more recently published, Indonesia dalam arus sejarah, Volume V (Lapian and Abdullah 2012). However, the goal of this article is to the seek different narratives in the Age of Motion. Rather than following political activism, I turn my attention to the activities of a group of people, mainly members of the Javanese elite, bureaucrats, and scholars, who were engaged in cultural enterprises in this period, regarding these as an equally important phase in the national movement in Java. Their activism, especially in the Panji-related arts and cultural expressions as an example of the development of culture, is the theme of this article. This story begins in the western part of Java, continues in the eastern region and ends in the heart of Javanese culture, the centre of the island. Indeed, this story is only an initial study of the many cultural activities flourishing in this period but it is essential to highlight the development of the Panji-related arts as a part of those activities around Java.

\section{Panji AND the Cultural DeVelopment FROM WEST to EASt JaVA}

Panji dances were already popular in West Java in the nineteenth century. In Ritter, Hardouin, and Lange's book (1855), Java; Tooneelen uit het leven karakterschetsen en kleederdragten van Java's bewoners in afbeeldingen naar de natuur geteekend, there is a chapter dedicated to topeng babakan accompanied by an illustration by Hardouin. As Laurie Ross (2016) points out, the ronggeng ${ }^{3}$ dancer depicted in this book on page 125 is probably preparing to dance a Panji story. She reached her conclusion because of the presence of a white mask in the lower right corner of the picture. ${ }^{4}$ Furthermore, she adds that the costume of the leading dancer or dalang is that of Panji. From head to toe, the dancer's attire resembles that traditionally worn by Panji. The headdress closely resembles a tekes. ${ }^{5}$ The sewn cloth worn around the chest and the batik dodot $t^{6}$ around the lower half of the body is draped in front giving the appearance of a long skirt. Before a dancer or dalang can perform a Panji story, he begins the performance with ronggeng.

\footnotetext{
3 A ronggeng or talèdhèk is a professional dancing woman (Brakel-Papenhuyzen 1995: 545).

${ }^{4}$ Ross obviously identifies the white mask in this picture with the character of Panji. However, in eastern Java, the white mask is used by Sekartaji.

${ }^{5}$ Kieven (2013: 60-62) discusses the meaning of the term tekes in relation to the depictions of Panji on temple reliefs in which he wears a specific type of headdress. She comes to the conclusion that the term tekes does not necessarily denote this specific headdress, although this has been suggested by some other authors.

${ }^{6}$ Batik dodot is the batik cloth wrapped over the dalang's undergarments (Ross 2016: 299).
} 
Currently, the term ronggeng is often associated with prostitution, immoral, and other negative images. Nevertheless, according to C.M. Pleyte (1916: 271), initially the ronggeng dance was performed for the gods and other religious purposes. When many Javanese people embraced Islam, it was ascribed to Allah. Like the Devadasis of Tamil Nadu in India, the meaning of ronggeng has changed over time, assuming a pejorative connotation. Contrary to this argument, Clara Brakel-Papenhuyzen (1995: 567-568) argues that the origin of ronggeng or talèdhèk is strongly related to the agrarian culture in Mainland China. She advocates the explanation of Go Gien Tjwan (1966) who writes that there are many striking similarities between the institution of ritual wedding dances in Chinese and Javanese society. Rather than serving any ritual or religious purposes, several recent studies indicate that the professional dancing woman's performance, including ronggeng, was principally purely for entertainment.

Ritter, Hardouin, and Lange (1855) state that the dancer or dalang was a woman. However, in the nineteenth century a woman's access to public space was limited. The dancer, therefore, would have been a young man rather than a woman. A modern educated nobleman, Pangeran Aria Achmad Djajadiningrat (1877-1943), once said that this was the case when he was an adolescent. He came from the noble family in Banten, West Java. In his memoires, Achmad Djajadiningrat (1936) shares his experiences in becoming toekang tari topeng or mask dancer. As was the custom among the families of the district Regents and of other high-ranking indigenous officials in that era, each maintained their own troupe of dancers. The members of the dance groups were usually relatives. Achmad's uncle, the Regent of Pandeglang, observed this custom to the letter. His uncle appointed a skilfull dance teacher to train his children and other relatives, including Achmad. His teacher asked Achmad to learn the Tari Kalana, which was more difficult than the dances of other characters. Kalana or Klana is one of the main characters in the cosmology of the Panji dance. In topeng dance in the Cirebon tradition, there are five core characters. Panji is always danced first, followed by Samba, Rumyang, Tumenggung, and Klana. The character of Klana was said to come from Bewarna, the region of which he was king (Ross 2016: 295). The name of Bewarna does slightly resemble Bewarna, the city which C.C. Berg (1954: 200) suggests was the kingdom Urawan, one of the essential kingdoms in Panji tales.

In part of his explanation, Achmad Djajadiningrat (1936) depicts the attire which he wore for the dance in detail:

At our first show, my aunt decked me out with all of her gold and diamond jewellery. Not only were my neck and hands adorned, the specific headdress (tekes) I was wearing was studded with diamonds and other gems. My belt was made of gold inlaid with diamonds (benten) [...] The mask which I usually wore was too large on my face, therefore a new mask which fitted my face had to be made [...] My whole body sparkled brilliantly. And there was not a spare inch 
of room on my headdress (tekes). It was ablaze with gems and diamonds. ${ }^{7}$ [My English translation.]

His description conveys that Panji in the form of topeng dance was popular in the western part of Java at the end of the nineteenth century or on the eve of the Age of Motion.

Achmad Djajadiningrat had received an Islamic education at a pesantren before his family sent him to a Dutch family to acquire a western education. This latter stage in his schooling introduced him to the upper echelons of late colonial society. He was one of the few adipatis or regents in Java and Madura who could speak and write Dutch fluently. ${ }^{8}$ Besides being appointed a regent like his father and uncle, Achmad Djajadiningrat also served as a member of the Volksraad (the People's Council) and was even appointed to the Raad van Nederlandsch-Indië (the Council of the Netherlands East Indies), the highest administrative body in the colonial administration which functioned under the governor-general.

Besides his work as Regent of Serang, Achmad Djajadiningrat was involved in many cultural activities, especially in Batavia and the province of West Java. In 1921, he was a member of the regional committee of the Tweede Congres van het Java-Instituut (the Second Congress of the Java-Institute) in Bandung. He was responsible for the preparation of the accompanying exhibition, in which the committee had decided to showcase many traditional arts of the whole Island of Java. Achmad Djajadiningrat also played an essential role in the traditional Sundanese theatre with his patronage of the play of "Loetoeng Kasaroeng", paying particular attention to the old Pajajaran style traditional costumes which the protagonists wore. The design of the traditional costumes for the dancers was possible as the fruit of Achmad Djajadiningrat's investigations into in the ancient Baduy tribe, reputedly a remnant of the Pajajaran kingdom who had managed to preserve religion and old customs deep in the mountainous interior. ${ }^{9}$

Achmad Djajadiningrat became a member of the Volksraad and served as the representative of the party Nederlandsch Indische Vrijzinnige Bond from 1918 to 1929. The Volksraad was the quasi-house of representatives for

\footnotetext{
7 Pada pertoendjoekan kami jang moela-moela itoe bibi saja telah menghiasi saja dengan segala perhiasan emas dan intan jang ada dalam taroehannja. Boekan sadja leher dan kedoea belah tangan saja jang dihiasi, tapi sampai-sampau kepada destar jang saja pakai (tekes) poen telah penoeh ditaboeri dengan intan berlian jang besar-besar. Ikat pinggang saja dari pada emas bertatahkan intan dan berlian (benten) [...] Topeng jang biasa saja pakai, terlaloe besar di moeka saja, oleh karena itoe haroeslah diperboeat topeng baroe jang sesoeai pada moeka saja [...] Seloeroeh toeboeh saja telah tjemerlang berkilau-kilauan. Sedangkan pada destar saja (tekes) poen ta' ada lagi tempat jang terloeang. Seloeroeh destar itoe telah penoeh ditaboeri dengan intan dan berlian. (Djajadiningrat 1936: 37-38).

8 Another adipati who was also fluent in Dutch was Raden Mas Adipati Ario Sosroningrat, the Regent of Jepara and the father of Raden Adjeng Kartini and Raden Mas Pandji Sosrokartono. Regarding the priyayi and the bureaucrat elite in Java, see Sutherland 1976.

${ }^{9}$ Programma voor het Congres van het Java-Instituut te houden te Bandoeng van 17-19 juni 1921, page 24; "Soendaneesche kunst op het Java-Congres" in Het Vaderland: Staat- en Letterkundig Nieuwsblad 26-07-1921, page 1.
} 
the Indies. Initially the powers of this institution were limited. However, after 1925, the government granted it more powers, largely confined to the legislative process. Thereafter all laws could be enacted and passed only after Volksraad had given its approval. This change meant that various acts of legislation had to be delayed, including the protection of ancient monuments or the Monumenten Ordonantie (Boomgaard 1999: 269). This upshot of the delay was that the issue of cultural heritage preservation became more widespread and reached a broader audience. As a part of it, F.D.K. Bosch, the head of Oudheidkundige Dienst or Archaeological Office, delivered various speeches on this subject in national and international forums (Bosch 1929: 201). Finally, in 1931, the Monumenten Ordonantie for the Netherlands East Indies was published. Despite his resignation in 1929, Achmad Djajadiningrat also contributed to the first legislation on cultural heritage in Indonesia. Many cultural nationalist supporters remarked that this legislation was an essential part of the cultural awakening of the Indonesian nation (Djåwå 1931: 100-101).

Another adipati or regent who was involved in the development of the Panji arts, especially topeng dance, was Raden Adipati Ario Soerio Adiningrat. He served as Adipati of Malang from 1898 to 1934 (Sutherland 1974: 33). According to Onghokham (1972: 111-121), Malang has long been a centre of topeng culture. There is one particular place in the Malang area named Kepanjen which many people believe derived its name from the hero Panji (Ke-Panji-an). In the dance performance, for the characters based on the stories of Panji-cycle, topeng, Malang has its own masks, costumes, and style of dancing. Soerio Adiningrat was known as a great sponsor of this art in the 1930s. ${ }^{10}$ A peasant from the small village of Polowijen, Reni, became a famous Malang topeng carver under the patronage of Soerio Adiningrat. The latter contributed to the advancement of this craft by supplying materials such as gold leaf, paint, and wood, as well as setting a high artistic standard. Therefore, it is not surprising that nowadays the topeng made by Reni are considered the classic standard by local people and topeng collectors. Indeed some people, especially topeng collectors, treated them as a pusaka or heritage items. The sacredness of the topeng made by Reni has accrued because of the knowedge current among the Javanese people that the topeng had been ordered by an exalted figure such as adipati and later even by one of the princes of a central Javanese court, Mangkunagara VII.

In his famous book, Javaanse volksvertoningen, Pigeaud (1938) devotes an extensive discussion to topeng and its related performance in Java and Madura. It begins with the survey conducted by the Java-Instituut in 1928 and continues with his assignment by the board of the Java-Instituut to collect information on the many kinds of topeng and other dances being performed in Java and Madura. In this book, the retired Regent of Malang, Ario Soerio Adiningrat, appears to have been the most active patron of topeng dance in East Java. According to his answer to Pigeaud's questionnaire:

${ }^{10}$ Correspondentie met J. Erkelens, vertegenwoordiger van het KITLV te Jakarta, betreffende de geschiedenis van het Java-Instituut en de persoon van S. Koperberg, 1980-1982, 2-7-1982. 
[...] that it [topeng dance performance] still occurs in many places, but it has been in a sharp decline during the last twenty-five years. In 1928 there were twenty-one (fairly elaborate) sets of masks in the Malang Regency. The most famous mask players came from the Putjangsanga village in the under-district of Toempang. In the old days, the patinggi (headman) of that village, called Saritroena, was famous for his mask dances. In Malang and surrounding regions not long ago all boys and men of the prijaji class would have been able to perform mask dances: prijajis often performed several dances at feasts. [...] Regarding the topeng dance performances, the following can be said. There are different groups of mask players with their dalang who are hired to perform at a party, usually a family feast and alsoa sugar-cane ritual communal feast at a factory. The players, however, are not, or not at all,professional players, but farmers and also come from the wealthier classes. ${ }^{11}$ [My English translation.]

Almost all of the adipatis in East Java felt pessimistic about the future of topeng dance. Raden Adipati Ario Surjowinoto, the Regent of Gresik, reported that topeng dance was no longer a popular performance in his regency. In the past, various villages had performed dances annually at the Sedekah Desa or Village Festival, an event held as a thanksgiving topeng Panji after the harvest. However, this kind of event was gradually disappearing in many parts of Gresik. Local people preferred to hold wayang purwa or tayuban rather than topeng Panji dance. This situation had been exacerbated by the attitude of the younger generation who felt no compulsion to continue this tradition after the older generation of dancers had passed away.

In this topeng dance performance during Sedekah Desa in Gresik, Dewi Sekartaji played an indispensable role. Pigeaud (1938) suggests that perhaps this might have been related to the worship of Dewi Sri, the Goddess of fertility for Javanese people.

Sěkartadji (the consort of R. Panji) played an important role in this mask performance. Bundles of food were hung as decoration on the poles protruding from the improvised shelter in which the performance was given. These sources intimate that this sěděkah-děsa, as elsewhere, was particularly associated with fertility and food. Perhaps it might perhaps also not be presumptuous to assume that, on the occasion of this festival, Dèwi Sěkartadji is the representative of she who is usually called Dèwi Sri elsewhere. As it is common knowledge that Dèwi Sri is generally thought of in relation to rice, and that in some regions her "way", her lakon, is still considered suitable to be presented at the festival of the rice harvest.

${ }^{11}[. .$.$] dat het nog wel op vele plaatsen voorkomt, maar dat het toch in de laatste 25$ jaar sterk aan het afnemen is. Er waren in het regentschap Malang, volgens opgave, in 192821 (enigszins uitgebreide) stellen maskers. De bekendste maskerspelers kwamen van de desa Poetjangsanga in het onderdistrikt Toempang; in vroeger tijd was de patinggi van die desa, Saritroena geheten, beroemd om zijn maskerdansen. In Malang en omliggende landstreken behoorden nog niet lang geleden alle jongens en mannen uit de prijaji-stand maskerdansen te kunnen uitvoeren: bij feesten werden dan ook niet zelden verscheidene dansen door prijaji's gedanst. [...] Wat betreft de maskerspel-opvoeringen blijkt het volgende. Er zijn verschillende troepen maskerspelers met hun dalang, die zich verhuren om een opvoering te geven bij een feest, meestal een familiefeest of ook wel een malfeest van een fabriek. De spelers zijn echter niet of niet allen beroepsspelers, maar landbouwers, ook van de gegoede stand. (Pigeaud 1938: 142-143). 
This presumed equivalence of Dèwi Sěkartadji and Dèwi Sri (and the subsequent one of Raden Panji with Sědånå or Wisnoe, and so forth), albeit fits perfectly logically into the older Javanese way of thought and has also been accepted as in the literature, I have not yet come across in the context of the mask performance. Perhaps, this stems from the sources received from the other [Javanese] side which claimed that, in the past, and then only rarely, in the Soerabaja and Sidaardja Regencies, wajang gědog performances were given, as a special event, precisely at sěděkah-boemi. Panji stories are performed only in wajang gědog. So, here one sees a sacred use of the mask performance and the Panji stories united. ${ }^{12}$ [My English translation.]

In Bangil Regency, the situation was even worse than in Gresik. Raden Adipati Ario Harsono ${ }^{13}$ reported that foreign culture, Arab influence in particular, threatened the indigenous traditions of Javanese people, including the topeng dance. The growth in the numbers of the Arab population in this area since the nineteenth century had been detrimental to the local culture. This remark elicited the following response from Pigeaud (1938):

[...] Muslim religious studies, whose primary language is Arabic, have exerted an influence on Java, probably moat heavily through kitabs, religious writings, imported from the centres of the Islamic studies elsewhere or studied there by Javanese, rather than by teaching and missionary endeavours of Arabs who have settled here. Of course, the influence, of both the kitabs and the Arabs personally, will have first and foremost affected the kaoem group.

It was only in the later period, perhaps only since the first half of the last century, that it has been assumed that a movement in favour of the religious practice of Islam, and hence the replacement of some old Javanese customs often through an Arabization, in the kaoem group of stricter Muslims, has taken shape. This movement has been reinforced by economic development and the increase in traffic in these regions, including with countries outside the Archipelago.

${ }_{12}$ Bij dit maskerspel speelde Sěkartadji (de gemalin van R. Panji) een belangrijke rol. Aan de palen van de loods, waar de opvoering gegeven werd, werden bundeltjes etenswaren opgehangen als versiering. Uit deze mededelingen mag men wel opmaken, dat deze sěděkah-désa, zoals ook elders, in het bijzonder met vruchtbaarheid en voedsel in verband stond. Misschien mag men ook vermoeden, dat Dèwi Sěkartadji bij gelegenheid van dit feest de vertegenwoordigster was van haar, die elders and anders meestal Dèwi Sri genoemd wordt. Men weet dat Dèwi Sri vrij algemeen in verband wordt gedacht met de rijst, en dat haar "weg", haar lakon, ook nu nog in sommige streken bij uitstek geschikt wordt geacht om voorgesteld te worden bij het feest van de rijst.

Deze hier te vermoeden gelijkstelling van Dèwi Sěkartadji met Dèwi Sri (en de daaruitvolgende van Raden Pandji met Sědånå of Wisnoe, enz.), ofschoon op zich zelf in de oude Javaanse denkwijze volkomen "logisch" passend, en in de letterkunde ook wel aan te wijzen, heb ik ten aanzien van het maskerspel nog niet ontmoet. Misschien is hiermede echter in verband te brengen de mededeling, van andere zijde ontvangen, dat vroeger, en zelden, in de regentschappen Soerabaja en Sidaardja wel wajang-gédogopvoeringen werden gegeven, juist bij sěděkah-boemi, als iet bijzonders. met wajang-gédog kunnen alleen Pandji-verhalen opgevoerd worden. Men ziet hier dus een sakraal gebruik van het maskerspel en de Pandji-verhalen verenigd. (Pigeaud 1938: 135).

${ }^{13}$ Compare the names of East Javanese adipatis with the work of Sutherland $(1973,1974)$. See also Clara van Groenendael (1995) in the appendix which contains of the list of the regents who did respond to the Java-Insituut's questionnaire. The only name to differ is that of the Regent of Bangil. In Pigeaud's book this is given as R.A.A. Harsånå, which corresponds to with Sutherland. Clara van Groenendael mentions the name of R.A.A. Hassana. 
Whereas, as the Regent of Bangil assumes the influence of the Arabs has changed the customs of an entire city, once must understand that the kaoem group has exerted such a great influence on the population that its Arabizing customs have been widely followed. This is the case, probably not only in Bangil, but in many places along the entire north coast of the Javanese country and in Madura. Also do not forget Banten and Batavia, Tegal, and Pekalongan. ${ }^{14}$ [My English translation.]

The region of Sidoarjo has a long tradition of topeng dance, which differs slightly from other areas in East Java. According to local tradition, Sidoarjo is believed to have been the location of Jenggala, the kingdom of Panji. The dance has been particularly associated with the Tanggulangin and Sidokare areas of this regency. Raden Tumenggung Ario Soemodipoetro, the Regent of Sidoarjo, in response to the Java-Instituut's survey, explained that many people still made offerings to the ancestors before performing the topeng Panji dance. The dalang of topeng Panji group usually preserved specific sacred topeng masks among other masks. The sacredness of this topeng depended on many factors, but chief among them was the primary material of which the topeng was made. The most essential element in the topeng was the wood from the waru or coast cottonwood (Hibiscus tiliaceus) and the pule or Indian devil tree (Alstonia scholaris). The characters who usually donned a sacred topeng were Klana and Gunungsari. Many topeng dances groups journeyed to the areas surrounding Sidoarjo, including Jombang and Mojokerto. Their audiences were drawn not only from the Javanese but also the Chinese population. The troupes earned their highest fees from giving performances in front of Chinese families houses and klenteng (Chinese temples), in the brief period between the Chinese New Year and the Cap Go Me Festival (Pigeaud 1938: 140-141). ${ }^{15}$

Returning to Gresik, to the north of Surabaya, in the early of the twentieth century Tjoa Sien Tik, the Captain of the Chinese community, was a patron of the Javanese arts, including topeng dance. He owned a set of topeng which consisted of 168 masks as well as a complete set of gamelan instruments. Many troupes of topeng dancers borrowed his collections whenever they played. As mentioned, the topeng performances in Gresik were then on the decline as a

${ }^{14}$ [...] De Moslimse godsdienstwetenschappen, die het Arabisch tot voertaal hebben, hebben hun invloed op Java uitgoefend, waarschijnlijk veel meer door middel van kitab's, godsdienstige geschriften, uit de hoofdzetels van de Islam-wetenschappen elders hier ingevoerd, of daar door Javanen bestudeerd, dan door onderricht en zendings-arbeid van hier gevestigde Arabieren. De invloed, zowel van de kitab's als van de Arabieren persoonlijk, heeft natuurlijk allereerst op de kaoemstand gewerkt.

Pas in de latere tijd, misschien pas ongeveer sinds de eerste helft van de vorige eeuw, heeft, zo mag men aannemen, ingezet de beweging ten gunste van een rechtzinnige Islam-beoefening, en daarmee voor de vervanging van sommige ouderwets-Javanistische gebruiken bij de kaoemstand door strenger Moslimse, vaak Arabiserende. Deze beweging werd verstrekt door de economische ontwikkeling en de toename van het verkeer in deze streken, ook met landen buiten de Archipel. Waar, zoals de Regent van Bangil aanneemt, de inwerking der Arabieren de gewoonten van geheel een stad heeft gewijzigd, heeft, zo moet men begrijpen, de kaoemstand een zo grote invloed op de bevolking gekregen, dat zijn Arabiserende gewoonten in wijde kring navolging vonden. Dit is het geval, waarschijnlijk niet alleen in Bangil, maar in vele plaatsen langs de gehele Noordkust van het Javaanse land en op Madoera. Men denke ook aan Bantěn en Batavia, Těgal, en Pěkalongan. (Pigeaud 1938: 141-142).

${ }^{15}$ For a comparison with the situation in West Java, see Ross (2016). 
result of certain circumstances. Furthermore, the family of Tjoa Sien Tik sold his topeng collections to the Stedelijk Historisch Museum Soerabaia (Images 1 and 2), which had been founded by G.H. von Faber in the year 1936 (De Indische Courant 7-12-1936). In the preparatory work prior to the establishment of a municipal and provincial museum in Surabaya, Von Faber worked in collaboration with many parties. He was directly assisted by the incumbent head of the Oudheidkundige Dienst, F.D.K. Bosch, and from the recreation and tourism sector, the Algemeene Bond van Hotel Houders in Nederlands Indië (ABHINI). This set of topeng had already been exhibited in Surabaya in 1926 during the Fourth Congress of the Java-Instituut. Other examples of Panji art which were also showcased in this congress were topeng dance from Malang and wayang krucil ${ }^{16}$ from Blitar (De Indische Courant 19-7-1926).

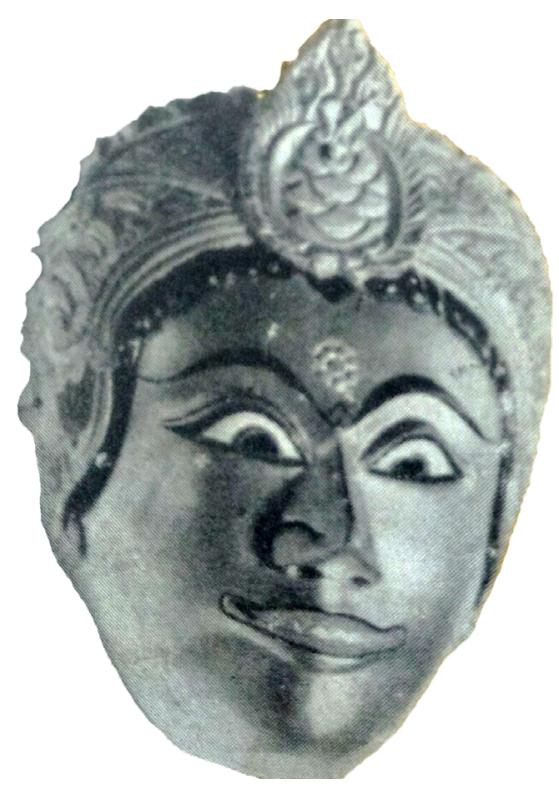

Image 1. Panji Rawitan mask in the collection of Mpu Tantular Museum, bought from the Tjoa Sien Tik family in 1937. (Courtesy of the Mpu Tantular Museum, Sidoarjo). ${ }^{15}$

Pigeaud (1938) writes that the main Panji characters, such as Panji, Gunungsari, Angreni, Kilisuci, Klana, and others, were dominant in these collections. Besides the "classic" Panji tales, other tales based on the Indian epics The Mahabharata and The Ramayana as well as Javanese tales such as Damarwulan and Menak were enacted in performances. Nowadays, the Museum which was established by Von Faber is managed by the East Java

${ }_{16}$ Wayang krucil is a puppet performance similar to wayang kulit, but it uses a puppet which made of flat wood, with arms and hands made of leather. The name of krucil is a reference to their smaller size compared to wayang kulit, only $\pm 30 \mathrm{~cm}$. Wayang krucil also known as wayang klithik.

${ }^{17}$ I would like to express my gratitude to Drs Sadari (Head of Exhibitions and Education of the Mpu Tantular Museum), who provided me the Images 1 and 2 from the collection of the museum. 
Cultural and Tourism Agency under the new name the Mpu Tantular Museum. When I visited the museum in October 2019, I had a chance to look at these collections. Almost all of them are kept in good condition. Some of the masks had travelled quite extensively to exhibitions outside East Java. The curator of the museum only displays the newer collection of masks which are distinct from the above-mentioned collection in the permanent exhibition of Mpu Tantular Museum.

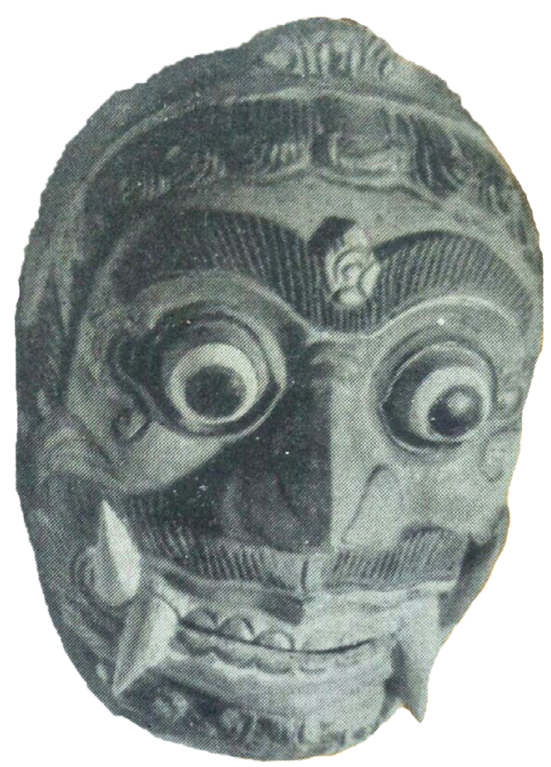

Image 2. Klana Prabu Jaka (?) mask in the collection of the Mpu Tantular Museum, bought from the Tjoa Tien Sik family in 1937. (Courtesy of the Mpu Tantular Museum, Sidoarjo).

THE CENTRIPETAL DiRECTION OF CULTURAL DEVELOPMENT IN CENTRAL JAVA

The Java-Instituut was the initiator of almost all the activities mentioned above. Pigeaud would not have been able to complete his work on Javanese folk arts if the Institute had not sent the questionnaire to all Regents in Java and Madura and assigned him to collect and collate the information on the topeng in Java and Madura. The results were impressive. The Java-Instituut was the most respected cultural institution not founded and not led by the Dutch since its beginning. The foundation of this institute was the outcome of a recommendation from the Congres voor Javaansche Cultuur-Ontwikkeling or the Congress of Javanese Cultural Development, which was held in 1918. According to its statutes, the Java-Instituut's goal was to develop the native culture of the Javanese, Madurese, Sundanese, and Balinese. To reach this goal, its plan was to collect and record as much material from Javanese culture as possible. Furthermore, it wanted to promote knowledge and understanding of Javanese culture by holding congresses, exhibitions, discussions and by issuing publications, as well as other activities. The founders also decided that 
this institution would be disbanded twenty-nine years after its establishment on 4 August 1948 (Djåwå 1921: 65-66).

Prince of Mangkunagara, head of the second court in Solo, Pangeran Prangwedana (later Mangkunagara VII), and Dr Hoessein Djajadiningrat were the main actors in the establishment of the Java-Instituut. Mangkunagara VII was a powerful and influential patron of Javanese culture in the early twentieth century. He had studied at Leiden University for three years. Just before he travelled to the Netherlands, he met Dr Hoessein Djajadiningrat for the first time in Batavia. At this meeting, Hoessein Djajadiningrat suggested him to meet Christiaan Snouck Hurgronje, the Professor in Indology. In Leiden, for the first time he made the acquaintance of Noto Soeroto, a young nobleman from the Pakualaman court of Yogyakarta (R.M. Haryo Soerjosoeparto 2017: 203-208). They began to collaborate on many cultural activities, especially writing and translating poems. They also had an opportunity to join the volunteer force of the Netherlands in 1914. The following year, he returned to Java and was elected chairman of Boedi Oetomo before he succeeded his uncle as Prince of the Mangkunagaran in 1916.

As the new ruler of a Javanese kingdom, he gave his whole-hearted support to burgeoning Javanese nationalism endorsed by various organizations, including Jong Java (Young Java) and the Comité voor het Javaans Nationalisme (Committee for Javanese Nationalism). This latter organization published the journal Wederopbouw (Reconstruction), whose aim was to re-awake and re-build the imagined prosperity of the Javanese Majapahit Kingdom. Prangwedana also inspired this kind of nationalism by promoting the use of examples of Indian culture and nationalism, particularly the works of Rabindranath Tagore, whose poetry he translated into Javanese while he was in Leiden (Djajadiningrat-Nieuwenhuis 2006: 102-103). Given his record, it was not surprising that he was a patron of the first Congress of Javanese Cultural Development in 1918. This event attracted a great deal of attention from many people and at least 1,200 people attended this congress.

Hoessein Djajadiningrat played an indispensable role in the JavaInstituut alongside Mangkunagara VII. He was the first Indonesian to receive a doctorate from Leiden University. He was the younger brother of Achmad Djajadiningrat, referred to in the previous section. He headed the Java-Instituut from the its beginning until this institution collapsed after Mangkunegara VII passed away in 1944. He was responsible for at least six cultural congresses in Java and Bali between 1920 and 1937 and many more exhibitions of performing arts, traditional handicrafts, traditional weapons, and other aspects of Javanese culture. Nor did his activities stop there. In 1924, when the first Rechtshogeschool or Law School was established in Batavia, he was appointed as professor of the Malay language. Many years later, he worked with another cultural institution, the Bataviaasch Genootschap van Kunsten en Wetenschappen, as a curator and its director (Pijper 1961: 404406). Moreover, from 1920 to 1925, he assisted the government as an advisor on native affairs. He replaced his brother, Achmad, as a member of the Raad 
van Indie or the Council of Indies from 1935 to 1939. Hoessein married Partini, the eldest daughter of Mangkunagara VII. This marriage brought Hoessein Djajadiningrat and Mangkunagara VII even closer together.

Mangkunagara VII was the most prominent of the Javanese rulers in the cultural development in this period. He was a great lover of all the traditional Javanese arts. He had many acquaintances nationally and internationally. He was extremely generous in giving scholars, especially in Javanese arts, history, and culture, many opportunities to have access his collections. Stutterheim and Pigeaud (1926) made many studies of his collections. One of these studies was on an inscription found during the excavation of the site of the Majapahit capital in Mojokerto (Stutterheim and Pigeaud 1926: 195). Mangkunagara VII had bought this inscription from Dr F.B. Klaverweisen in Surabaya; they had probably met at a Congress of the Java-Instituut. The latter had told Mangkunagara that this bronze-plate inscription had been found during excavations of the Majapahit capital site in Mojokerto and dated to AD 1379 (Stutterheim and Pigeaud 1926: 195). Later this inscription became known as the Renek inscription and is kept in the Mangkunagaran Museum. Stutterheim also assessed the archaeological collection of Mangkunagara VII. He published his findings in the journal Djåwå when he was serving as the head of the Oudheidkundige Dienst in the Netherlands East-Indies. ${ }^{18}$ Another scholar whom he supported was the art historian from America, Claire Holt, a friend of his, who often discussed the arts with Mangkunagara VII at his palace and even attended dance rehearsals conducted by the Prince himself (Holt 1967: 152-153). The Nobel laureate Rabindranath Tagore was also a guest in his mansion during the poet's visit to Java and Bali. Among the many other activities he pursued, he continued the mask collection in the palace which had been begun the previous century during the reign of Mangkunagara $\mathrm{V}$ (Djajadiningrat-Nieuwenhuis 2006: 105-106).

Mangkunagara $\mathrm{V}$ has also won fame as a patron of the Javanese arts. Mangkunagara V had contributed to the Colonial Expo in Paris, France, and Chicago, America, sending several masks from his collection (Bloembergen 2006: 127-128). He catalogued all his masks sticking labels on the inner forehead of each. Each tag contains the name of the character, many of them from Panji tales. Mangkunagara V did not restrict his mask collection to Central Java and the Panji tales. One specific mask in his collection is a Bima from Cirebon; Bima is a character from The Mahabharata and, as a Cirebon mask, has a style distinct from that of Surakarta. His son, Mangkunagara VII, continued his work in collecting masks from many parts in Java, Madura, and even Bali. Sometime in the 1920s, as a consequence of the financial crisis, the Cirebon court sold its mask collection to Mangkunagara VII. He purchased it with money from his savings. A similar fate befell the Malang masks in his collection. Some masks and other pieces of artwork were given as gifts by kinsmen of the Mangkunegaran dynasty residing outside of Surakarta. For example, the Wedana of Turen in Malang regency, Panji Diro Soegondo,

${ }^{18}$ This publication is Stutterheim 1937. 
was a close relative who gave Mangkunegara VII several masks as presents. He also played a role in collecting the Panji masks made by Reni, the famous mask carver from Malang (Ardus Sawega 2014: 114-117). See some Panji masks from Malang in the collection of Mangkunegara VII as illustrated in Image 3.

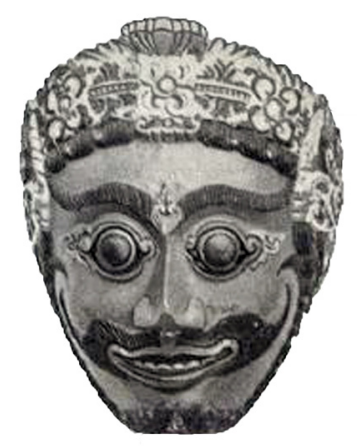

Afb. 56. Klånå Prabu Djåkå.

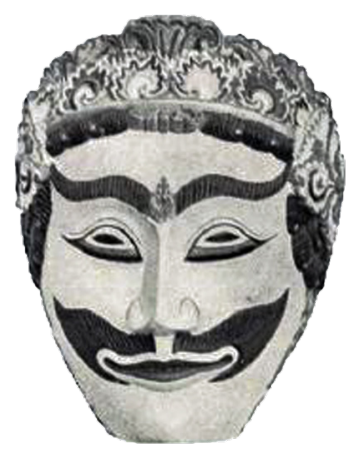

Afb. 58. Klånå Sěwandånå.

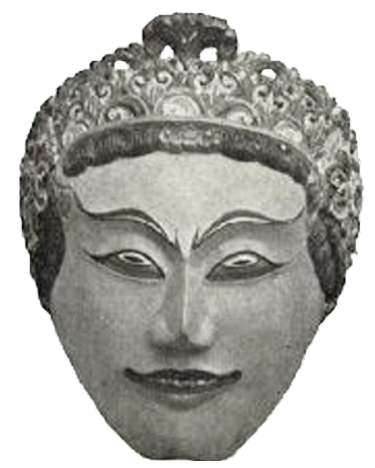

Afb. 60. Ragilkoening.

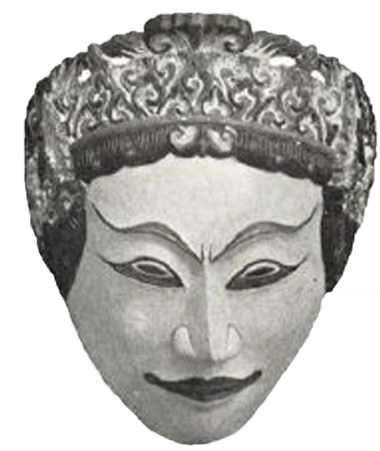

Afb. 57. Ratoe Djenggålå.

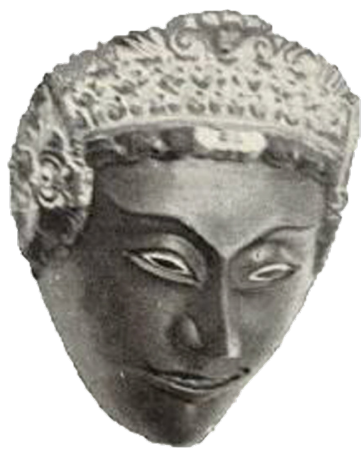

Afb. 59. Oude Pandji.

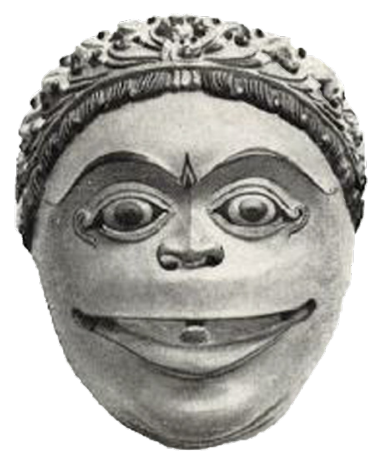

Afb. 61. Měnak Agoeng.

Afb. 56.t/m 61.

Image 3. Some topeng Panji from Malang in the collection of Mangkunagara VII. (Source: “Afb. 56 t/m 61" in Pigeaud 1938: 160). 
Despite his genuine fondness of Javanese arts and culture, Mangkunagara VII did not let this stand in the way of innovation and development. The modernization which he saw in his own country, and he has personally experienced in Europe, had an impact on his ideas about Javanese culture. One example of innovation in performing arts relating to Panji is the Larasdriya. This was first performed at the tenth anniversary of the accession of Mangkunagara VII in 1925. He wrote a play called "Tembem and his daughters", featuring new masks and new characters. However, this play was unusual because there were no central characters who were scions of royal houses such as Panji and Sekartaji. The main plot of this play is simple and represents the everyday life of the common people. At first, some commentators were puzzled by this new kind of performance. They thought they recognized the cycle of Panji tales but without the main characters of Panji. However, later they were impressed by Mangkunagara's innovative foray into the Javanese performing arts, combining it with new elements from the western theatre (J.S. Brandts and A. Brandts Buys-Van Zijp 1926: 105-109).

\section{CONCLUSION}

As has been intimated earlier in this work, this article is an initial phase in a more extensive research into Javanese cultural development in the late colonial period of Indonesia by the author. Various prominent figures who were part of the network of the Java-Instituut actively worked towards this development, fostering the Panji-related arts and cultural expressions. A few of them have been mentioned, in particular Hoessein Djajadiningrat and Prince Mangkunagara VII. This network won considerable deal of influence, not only on the regional level in Java, Madura, and Bali but also nationally in the Age of Motion and this lasted until the end of Dutch colonialism.

Nevertheless, this part of Indonesian cultural history still remains understudied more than a century later. To some extent, people like Hoessein Djajadiningrat and Mangkunagara VII are remembered in the official Indonesian historiography but this acknowledgement is limited to their contributions to the political sphere of the nationalist movement. In Sejarah nasional Indonesia, Volume VI (Kartodirdjo, Poesponegoro, and Notosusanto 1975), the first appearance of Hoessein Djajadiningrat occurs only in the Japanese occupation period, during which his role as a member of the Investigating Committee for Preparatory Work for Independence was especially outstanding. Similarly, Mangkunagara VII is remembered only as the founder of the first native scout organization in Indonesia dalam arus sejarah, Volume V (Lapian and Abdullah 2012).

However, this situation is nothing new because, as Tamzil (1938) states, the political-nationalists already dominated the discourse of nationalism in this very period. Nevertheless, voices were being raised about the importance of the contribution of the cultural nationalists. In 1918, Suwardi Surya Ningrat (later known as Ki Hajar Dewantara) commented on the positive impact of cultural nationalism, particularly Javanese nationalism, contrasting it 
favourably with political nationalism. This is what he had to say:

In contrast to cultural nationalism, which has a few disturbing effects, political nationalism is immediately characterized by its aggressive character. However, the former is not intended to be a struggle, but quiet propaganda externally and self-assured action internally, while in politics, nationalism must be the weapon with which the enemy must be beaten down, be this good or bad [...] Cultural nationalism, in this case, Javanese nationalism, is therefore first and foremost a cultural concept. It manifests itself in various ways, for instance, in the propaganda for the Javanese art, the act of preserving and developing the Javanese language, the fight against the pro-Dutch bias in education, the reaction to the intended change in dress by some countrymen, the fight against the abolition of many old rural customs and so forth [...] I have already said above that political propaganda is aggressive and is repellent to many, because the term "struggle" is inherent in the word "politics". Cultural propaganda, on the other hand, is usually sympathetic and we can experience this in abundance now, especially significant is the appreciation which has recently been accorded to Indonesian art in the Netherlands. While generally speaking, the decent Dutchman looks with disfavour on the political upheavals in the Indies, and those who profess the "Indië free from Holland" are either criticized or denigrated, the propagandists of Indonesian art in the Netherlands are welcomed everywhere with open arms and with great enthusiasm. ${ }^{19}$ [My English translation.]

This was the argument Suwardi Surya Ningrat's wrote for the Festschrift published to celebrate the tenth anniversary of Boedi Oetomo. His words give us to understand that the contribution of the people dubbed the cultural nationalists could not be overlooked in the Age of Motion. More studies were and are needed to deepen and to enrich our understanding not only of nationalist history but also the cultural history of Indonesia. The study, particularly of Panji-related arts and artistic expressions, is an exemplary case. In her analysis of Pigeaud's work, Clara van Groenendael (1995) explains the reason the Java-Instituut wanted to conduct an investigation into topeng in Java and Madura. There was a need to collect the information related to this kind

${ }^{19}$ In tegenstelling met het cultureele nationalisme, dat weinig afstootends in zich heeft, laat het politieke nationalisme zich dadelijk kenmerken door zijn agressief karakter. Maar het eerste beoogt ook geen strijd, doch rustige propaganda naar buiten en zelfbewuste actie naar binnen, terwijl in de politiek het nationalisme het wapen moet zijn, waarmee de vijand goedschiks of kwaadschiks moet worden neergeslagen [...] Het Javaansch nationalisme is alzo en cultureel begrip in de eerste plaats. Het manifesteert zich in verschillende uitingen, als daar zijn de propaganda voor de Javaansche kunst, de actie voor het behoud en de ontwikkeling van de Javaansche taal, de strijd tegen de verhollandsching van het onderwijs, de reactie tegen voorgenomen verwisseling van kleederdracht door sommige landgenooten, de strijd tegen afschaffing van vele oude landsgebruiken e.d. [...] Boven zeide ik reeds, dat politieke propaganda agressief is en menigeen afstoot, omdat in het woord "politiek"het begrip "strijd" aanwezig is. Daarentegen is cultureele propaganda meestal sympathiek en dit kunnen wij ook in dezen tijd ten overvloede ervaren. Vooral de appreciatie, die den laatsten tijd in Nederland voor de Indonesische kunst bestaat, is teekenend. Terwijl over het algemeen de fatsoenlijke Nederlander zich onwelwillend uitlaat over de politieke strevingen in Indië, en degenen, die het "Indië los van Holland" durven belijden, enkel smaad en hoon ontvangen, worden de propagandisten voor de Indonesische kunst in Nederland overal met open armen en met groot enthousiasme ontvangen. (Surya Ningrat 1918: 27-38). 
of art because many valuable things were on the verge of being lost in the upsurge of rapid changes in the early decades of the twentieth century. This situation obviously corresponds to the initial phase of the national movement as suggested by Hroch (2000).

In recent years, Indonesia has again seen a rise in enthusiasm for Panji in many areas, especially in Java. Many events and festivals showcasing Panji have been organized by the central government, regional governments and communities. Therefore, proper research and more studies should be carried out to shed more light on the collection of the Panji-related artefacts in museums and galleries which have still not yet adequately identified so as to inspire many more ideas and innovations based on their provenance.

\section{REFERENCES}

ARCHIVES AND PERIODICALS

Correspondentie met J. Erkelens, vertegenwoordiger van het KITLV te Jakarta, betreffende de geschiedenis van het Java-Instituut en de persoon van S. Koperberg. 1980-1982. [2-7-1982; Leiden University Libraries, Special Collections.]

Djåwå. 1921. "Het Java-Institut", Djåwå; Tijdschrift van het Java-Instituut 19 \& 20, XVI: 100-106.

Djåwå. 1931. “Uit de Javaansche cultuurbeweging; Vaststelling van een

Monumenten-Ordonnantie", Djåwå; Tijdschrift van het Java-Instituut 1, I: 65-66.

Programma voor het Congres van het Java-Instituut te houden te Bandoeng van 1719 juni 1921. Weltevreden-Batavia: Kolff.

De Indische Courant 19-7-1926, 7-12-1936.

Het Vaderland Nieuwsblad 26-7-1921.

BOOKS AND ARTICLES

Anderson, Benedict. 1983. Imagined communities; Reflections on the origin and spread of nationalism. London: Verso.

Ardus M. Sawega. 2014. Topeng Panji; Mengajak kepada yang tersembunyi. Solo: Balai Soedjatmoko, Semarak Candrakirana Foundation, Pemkab Malang.

Berg, C.C. 1954. "Bijdragen tot de kennis der Panji-verhalen", Bijdragen tot de Taal-, Land-en Volkenkunde 110(3): 189-216.

Bloembergen, Marieke. 2006. Colonial spectacles; The Netherlands and the Dutch East Indies at the World Exhibitions, 1880-1931. Singapore: Singapore University Press.

Boomgaard, Peter. 1999. "Oriental nature, its friends and its enemies; Conservation of nature in late-colonial Indonesia, 1888-1949", Environment and history 5(3): 257-292.

Bosch, F.D.K. 1929. "De bescherming van de volkskunsten in NederlandschIndië door een monumenten-wetgeving. Rede, gehouden op het Congres voor Volkskunst te Praag, October 1928", Djåwå; Tijdschrift van het JavaInstituut 4 \& 5, IX: 200-221. 
Brakel-Papenhuyzen, Clara 1995. "Javanese talèdhèk and Chinese tayuban”, Bijdragen tot de Taal-, Land-en Volkenkunde 151/4: 545-569.

Brandts-Buys, J.S. and A. Brandts-Buys-Van Zijp. 1926. “Wajang-feestspel te Djokdja", Djåzwå; Tijdschrift van het Java-Instituut VI: 91-110.

Djajadiningrat, Pangeran Aria Achmad. 1936. Herinneringen. Amsterdam/ Batavia: Kolff.

Djajadiningrat-Nieuwenhuis, Madelon. 2006. “Mangkunegoro VII and Rabindranath Tagore; A brief meeting of like minds", Indonesia and the Malay World 34 (98): 99-108.

Go Gien Tjwan. 1966. Eenheid in verscheidenheid in een Indonesisch dorp. Amsterdam: Amsterdam University Press.

Groenendael, Victoria M. Clara van. 1995. Java en Madura in de uitvoerende kunsten; Th.G.Th. Pigeauds volksvertoningen en latere studies: 1817-1995. Leiden: KITLV Uitgeverij.

Holt, Claire. 1967. Art in Indonesia; Continuities and change. Ithaca, NY: Cornell University Press.

Hroch, Miroslav. 2000. Social preconditions of national revival in Europe; A comparative analysis of the social composition of patriotic groups among the smaller European nations. Translated by Ben Fowkes. New York, NY: Columbia University Press.

Kahin, George, M. 1952. Nationalism and revolution in Indonesia (Studies in Southeast Asia). Ithaca, NY: Cornell University Press.

Kartodirdjo, Sartono, Marwati D. Poesponegoro, and Nugroho Notosusanto. 1975. Sejarah nasional Indonesia. Jakarta: Departemen Pendidikan dan Kebudayaan.

Kieven, Lydia. 2013. Following the cap-figure in Majapahit temple reliefs; A new look at the religious function of East Javanese temples 14th to 15th centuries. Leiden: Brill. [Open access: http://www.brill.com/following-cap-figure-majapahittemple-reliefs.]

Kroeskamp, H. 1974. Early schoolmasters in a developing country; A history of experiments in school education in 19th century Indonesia. Assen: Van Gorcum.

Lapian, A.B. and Taufik Abdullah (eds). 2012. Indonesia dalam arus sejarah; Jilid 5: Masa pergerakan bangsa. Bandung: Ichtiar Baru, Van Hoeve.

Legge, J.D. Intellectuals and nationalism in Indonesia; A study of the following recruited by Sutan Sjahrir in occupation Jakarta. Ithaca, NY: Cornell University Southeast Asia Program. [Cornell Modern Indonesia Project Series.]

Moriyama, Mikihiro. 2013. Semangat baru; Kolonialisme, budaya cetak, dan kesastraan Sunda abad ke-19. Depok: Komunitas Bambu.

Onghokham. 1972. "The wayang topeng world of Malang”, Indonesia No. 14 (October): 110-124.

Pigeaud, Th.G.Th. 1938. Javaanse volksvertoningen; Bijdrage tot de beschrijving van land en volk. Batavia: Volkslectuur.

Pijper, G.F. 1961. "Professor Dr. Pangeran Ario Hoesein Djajadiningrat; 8 December 1886-12 november 1960", Bijdragen tot de Taal-, Land-en Volkenkunde 117(4): 401-409. 
Pleyte, C.M. 1916. “De eerste ronggeng”, Tijdschrift voor de Indische Taal-, Landen Volkenkunde LVII: 270-272.

Poesponegoro, Marwati D. and Nugroho Notosusanto (eds). 2008. Sejarah nasional Indonesia Jilid VI. Jakarta: Balai Pustaka. [First edition 1975: Sartono Kartodirdjo, Marwati D. Poesponegoro, and Nugroho Notosusanto, Sejarah nasional Indonesia. Jakarta: Departemen Pendidikan dan Kebudayaan.]

Ritter, W.L., Ernest Alfred Hardouin, and H.M. Lange. 1855. Java; Tooneelen uit het leven karakterschetsen en kleederdragten van Java's bewoners in afbeeldingen naar de natuur geteekend. 's-Gravenhage: Fuhri.

Ross, Laurie Margot. 2013. "Performing piety from the inside out; Fashioning gender and public space in a mask 'tradition' from Java's northwest coast", in: Timothy P. Daniels (ed.), Performance, popular culture and piety in Muslim Southeast Asia, pp. 13-43. New York, NY: Palgrave Macmillan.

Ross, Laurie Margot. 2016. The encoded Cirebon mask; Materiality, flow, and meaning along Java's Islamic northwest coast. Leiden: Brill.

Shiraishi, Takashi. 1990. An age of motion; Popular radicalism in Java, 1912-1926. Ithaca, NY: Cornell University Press.

Soerjosoeparto, Raden Mas Haryo. 2017. Kisah perjalanan Pangeran Soeparto: Jawa-Belanda 14 Juni-17 Juli 1913. Alihbahasa Frieda Amran. Jakarta: Kompas Media Nusantara.

Surya Ningrat. 1918. "Het Javaansch nationalisme in de Indische beweging", in: Sosro Kartono, Noto Soeroto, and Surya Ningrat (eds), "Soembangsih" gedenkboek Boedi Oetomo 1908-20 Mei-1918, pp. 27-48. Amsterdam: Tijdschrift Nederlandsch Indië Oud \& Nieuw.

Sutherland, Heather. 1973. "Notes on Java's regent families; Part I", Indonesia No. 16 (October): 112-147.

Sutherland, Heather. 1974. "Notes on Java's regent families; Part II", Indonesia No. 17 (April): 1-42.

Sutherland, Heather. 1976. The making of a bureaucratic elite; The colonial transformation of the Javanese priyayi. Singapore: Heinemann. [Asian Studies Association of Australia, Southeast Asia Publications Series 2.]

Stutterheim, W.F. 1937. “De oudheden-collectie van Z.H. Mangkoenegara VII te Soerakarta", Djåwå; Tijdschrift van het Java-Instituut XVII: 1-112.

Stutterheim, W.F. and Th. Pigeaud. 1926. "Een Javaansche Oorkonde uit den bloeitijd van Madjapahit", Djåwå; Tijdschrift van het Java-Instituut VI: 195-204.

Tamzil. 1938. "De cultuur in de nationale beweging" , in: "Indonesia" Jubileumnummer uitgegeven ter gelegenheid van het 30-jarig bestaan van de Perhimpunan Indonesia: 1908-1938, pp. 237-246. Leiden: Perhimpunan Indonesia. 